Edith Cowan University

Research Online

ECU Publications Post 2013

2015

Sustainable water management for urban agriculture, gardens and public open space irrigation: a case study in Perth

\author{
Raju Sharma Dhakal \\ Edith Cowan University \\ Geoff Syme \\ Edith Cowan University \\ Edward Andre \\ Edith Cowan University \\ Charles Sabato
}

Follow this and additional works at: https://ro.ecu.edu.au/ecuworkspost2013

Part of the Agriculture Commons

10.4236/as.2015.67065

Dhakal, R. S., Syme, G., Andre, E., \& Sabato, C. (2015). Sustainable Water Management for Urban Agriculture, Gardens and Public Open Space Irrigation: A Case Study in Perth. Agricultural Sciences, 6(7), 676. Available here This Journal Article is posted at Research Online.

https://ro.ecu.edu.au/ecuworkspost2013/1711 


\title{
Sustainable Water Management for Urban Agriculture, Gardens and Public Open Space Irrigation: A Case Study in Perth
}

\author{
Raju Sharma Dhakal1 ${ }^{*}$, Geoff Syme1, Edward Andre1, Charles Sabato ${ }^{2}$ \\ ${ }^{1}$ Centre for Planning, Edith Cowan University, Perth, Australia \\ ${ }^{2}$ Water Corporation, Perth, Australia \\ Email: ${ }^{*}$ raju.dhakal@hotmail.com
}

Received 19 May 2015; accepted 19 July 2015; published 22 July 2015

Copyright (C) 2015 by authors and Scientific Research Publishing Inc.

This work is licensed under the Creative Commons Attribution International License (CC BY). http://creativecommons.org/licenses/by/4.0/

(c) (i) Open Access

\begin{abstract}
Urban agriculture has been increasingly popular as a form of modern agriculture in urban settings. It includes community gardens, fruit orchards, home gardens, veggie patches, public open spaces, reserves, urban forest, and recreational landscaping. However, irrigation using urban water supply has been identified as a major constraints for the development of urban agriculture. This study presents a sustainable water management trial at Butler, a northern sub-urban development in Perth, Western Australia, for urban irrigation. The trial system consists of a number of water saving features including untreated fit-for-purpose groundwater supplied via a third pipe network, drip irrigation, local weather station, soil moisture sensors connected with a local weather station, night time irrigation, soil enhancement with conditioning and mulching, and use of native plants and vegetation. The trial outcome was compared against controlled areas in terms of irrigation efficiency and sustainable water management for urban agriculture. The study demonstrated that a fit-for-purpose irrigation along with water sensitive land management could be a sustainable alternative for urban agriculture that would achieve a significant water saving and irrigation efficiency at urban settings. However, quality of untreated groundwater can be an issue while utilizing it for irrigation, but the research has shown that it can be managed with innovative irrigation techniques. This indicates that the fit-for-purpose irrigation system with water sensitive land management practices would be highly supportive in sustainable development of urban agriculture, vegetation and recreational landscaping.
\end{abstract}

\section{Keywords}

Urban Agriculture, Sustainable Irrigation System, Integrated Land and Water Management

\footnotetext{
${ }^{*}$ Corresponding author.
}

How to cite this paper: Dhakal, R.S., Syme, G., Andre, E. and Sabato, C. (2015) Sustainable Water Management for Urban Agriculture, Gardens and Public Open Space Irrigation: A Case Study in Perth. Agricultural Sciences, 6, 676-685. 


\section{Introduction}

Urban agriculture has become increasingly popular across the world that includes a variety of activities: community gardens and fruit orchard, home gardens and veggie patches, urban forest, public open spaces, reserves, urban forest and recreational landscaping [1]-[5]. Urban agriculture differs from traditional agriculture as it is integrated into densely populated areas with limited land for food production and recreation space [4]. Urban agriculture can bring diverse vegetative structures back into urban system, support local bio-diversity, and provide ecosystem services across fragmented habitats and spatial levels [6] that in turn can reduce the impact of climatic variability [7]. In addition to food production, urban agriculture can cater for a wide range of urban community needs, including cultivation of vegetables, medicinal plants, spices, mushroom, fruit trees, ornamental plants, and other productive plants [5] [8]. The production of crop and agricultural goods, within and around cities, with a motivation of personal consumption or income generation [9] [10] thus integrates the local, urban and suburban economic and ecological system [1].

Urban agriculture has a vital role in enhancing food production and bio-diversity, but that comes with significant costs and constraints [11] [12]. Albeit not required, urban agriculture utilizes significant amount of scheme water for growing foods and crops, which is usually expensive than agricultural water supplies [4] [7]. On the other hand, reducing outdoor use of scheme water for agriculture activities is a major component of many strategies to reduce urban water use and ensure reliable indoor water supply [4]. For instance, almost $40 \%$ of the scheme water is consumed for agricultural irrigation activities in urban and regional councils of Perth metropolitan. In drought period, the agricultural irrigation is normally restricted with a variety of bans (daytime and winter sprinkler ban), and demand management practices [13]-[16]. As a result, urban agricultural activities are not always supplied with sufficient irrigation, especially when they require most, hence affecting the continuity of food production and other agricultural activities. This condition is expected to be continued in WA, since a gap between water demand and supply is predicted to be 120 GL by 2030 [15]. In this context, an alternative irrigation system utilizing locally available fit-for-purpose water sources (e.g. groundwater) could have multiple benefits from helping water authorities in augmenting water supply and ensuring cheap and reliable irrigation for urban agricultural activities.

Previous studies in Australia and other countries have shown that alternative irrigation systems using groundwater and recycled wastewater are widely accepted for urban and regional agriculture, forestry and recreational landscaping [7] [17]-[22]. Wong [19] suggests that agriculture, garden and park irrigation are important avenues to utilize recycled water and nutrients within the build environment. This supports the integrated land and water management practices at respective levels by reducing water import into and net discharge out of the environment. Further, well-established urban agriculture activities would have potential to mitigate and adapt the climate change by reducing the urban heat island effects, managing micro-climate, and enhancing biodiversity and ecology [7].

Similar studies have shown a growing acceptance among Australian communities towards alternative irrigation systems [17] [18] [22]-[24]. Hurlimann [17] observed that the majority of Mawson Lake community in South Australia accepted the irrigation use of recycled water as a better option compared to drinking water for their home gardens, veggie patches and other urban agriculture activities. Similarly, Australia-wide case studies conducted by Davis and Farrelly [22]-[24] have shown that a number of alternative water systems can be best utilized for efficient irrigation system. In context of WA, a number of studies consider groundwater as a reliable and sustainable source for outdoor irrigation activities [16] [18] [25]-[27]. These studies indicate that using groundwater as an alternative source for urban agriculture is technically feasible and receiving growing community acceptance all over Australia.

In this context, a suburban area in Perth ("The Green") was selected for this study that has alternative irrigation system via third pipe network. The system utilized local groundwater from shallow aquifer $(20-60 \mathrm{~m}$ below the ground surface). 5 communal bores abstract the groundwater and supply to the irrigation ring without any treatment for irrigating the private gardens and the public open space in every alternate day [28]. This innovative irrigation system was investigated in terms of irrigation efficiency and its utility for urban agriculture. For that, total household drinking water and irrigation consumption, and total public open spaces usage in "The Green" were analyzed and compared with that of the surrounding suburban areas and Perth metropolitan. Further, public acceptance towards the groundwater as an alternative irrigation source was analyzed. 


\section{Description of the Studied System}

This study was carried out in "The Green” suburban community at Butler, Western Australia (Figure 1), where urban agricultural practices and recreational landscaping were being irrigated with an efficient irrigation system. Butler is a Greenfield suburban area of City of Wanneroo, which is $35 \mathrm{KM}$ north of Perth CBD. The development of "The Green" began in 2005 and still to finish. "The Green" was compared as an experimental area with its neighbouring suburban development, mainly Ridgewood as control and Perth metropolitan city. Ridgewood is an established metropolitan suburban area having similar geography, climate, and socio-demography; but lacking the groundwater irrigation system and having a separate activity locus.

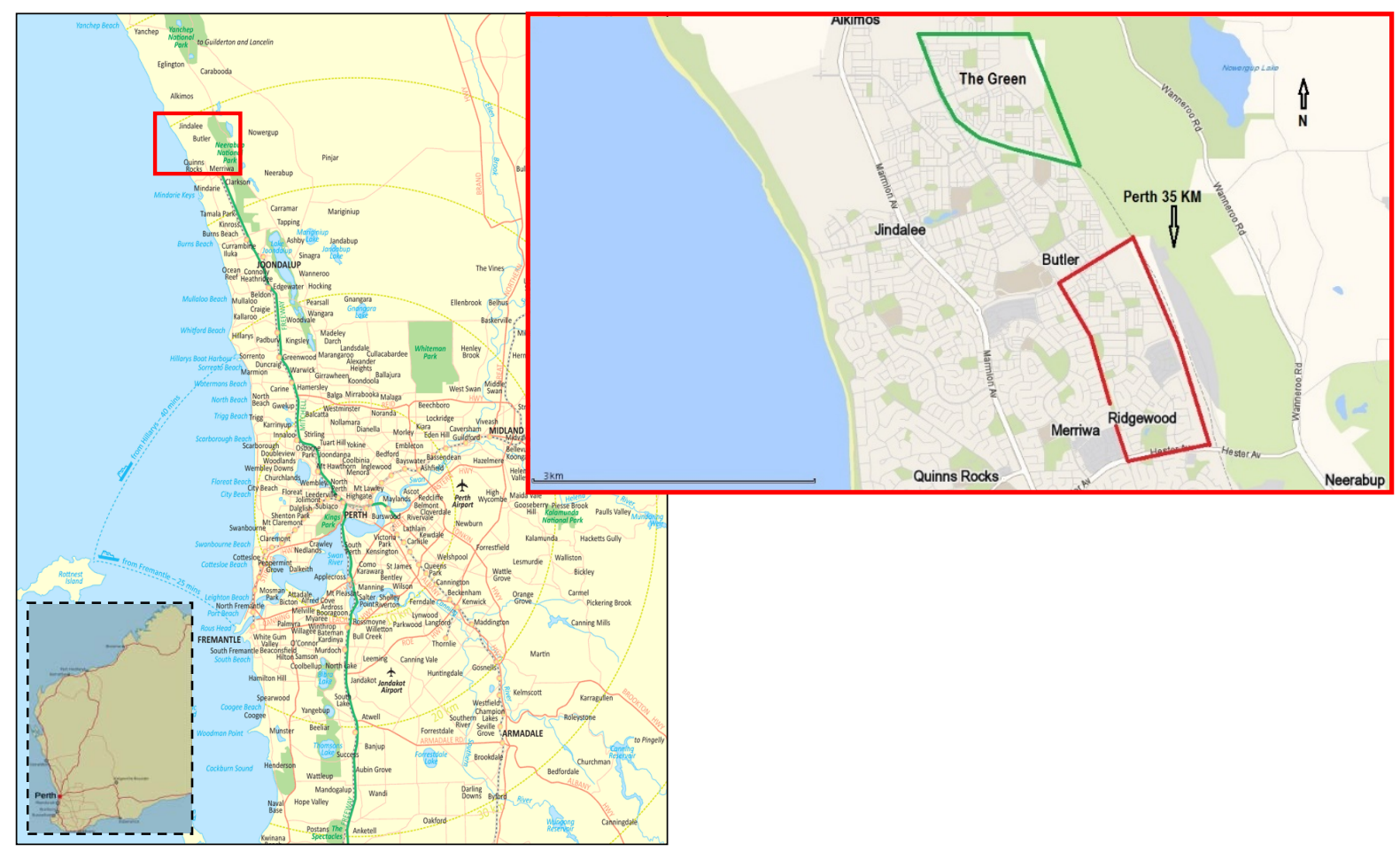

Figure 1. Location of the research area (Source: Contrywide Publication, Google Maps).

The irrigation system utilised the local groundwater without treatment, hence only used for irrigating home gardens, veggie patches, fruit orchards, community gardens, verges, public parks and ovals, urban forest, plantations, reserves, and bushlands [22] [29]. The irrigation system incorporated water smart technologies and water sensitive land management practices for the efficient consumption and optimisation of the groundwater supplied for outdoor agricultural activities, which include:

1) Auto-operated irrigation system

a) Weather station;

b) Soil moisture sensors.

2) Irrigation techniques for achieving efficiency and reducing human contacts

a) Night time irrigation;

b) Drips and sprinklers irrigation.

3) Soil conditioning and mulching

4) Water efficient agricultural activities at home

5) Water efficient agriculture, forestry, and recreational landscaping at community

\subsection{Automatic Irrigation System}

All agricultural and outdoor activities in "The Green" were automatically supplied with the local groundwater on the basis of local weather condition. Real time weather information was obtained from a local meteorological 
station (Figure 2(a)); such as temperature, rainfall, relative humidity, wind velocity, etc. This information was coupled with soil moisture information received from in-situ soil moisture sensors (Figure 2(b)) across "The Green" in controlling and operating the irrigation system. Thus established automated irrigation system not only provided irrigation virtually always when required, but also optimized the irrigation supply by avoiding overwatering, and irrigation after rain.

\subsection{Efficient Irrigation Techniques}

The gardens, parks, and urban agricultural activities in "The Green" were provided night time irrigation (10 p.m.-6 a.m.) that avoided evaporation loss, and also reduced possible health hazards to humans a direct contact with the groundwater. A number of efficient irrigation techniques were utilised, such as: unique pop-up sprinklers, and subsurface drip reticulation. The sprinklers were designed for spraying bigger droplets that would avoid wind-drifting and supplying enough water even in shorter operation windows. Similarly, subsurface drippipes (Figure 3(a)) supplied irrigation near the root zone of crops that not only improved irrigation efficiency but also reduce evaporation loss.

\subsection{Soil Conditioning and Mulching}

When preparing the garden beds and lands for other agricultural activities, the soil condition was improved with sufficient soil mixture, soil conditioner, and mulch as shown in Figure 3(a) and Figure 3(b). This would not only enhance the soil quality, fertility, as well as the water holding capacity but also reduce the evaporation loss from the surface.

\subsection{Water Efficient Agricultural Activities at Home}

Water efficient food production and gardening activities were encouraged at each household to reduce irrigation use. As shown in Figures 4(a)-(c), vegetable gardens and front gardens were established with less water demanding crops, vegetable, hardy turf, and bush. Mostly native plants were used, lawn areas were reduced to

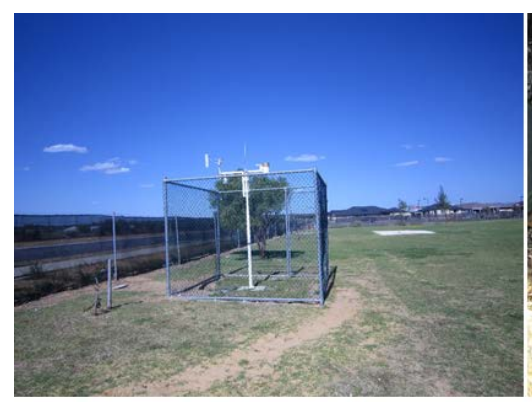

(a)

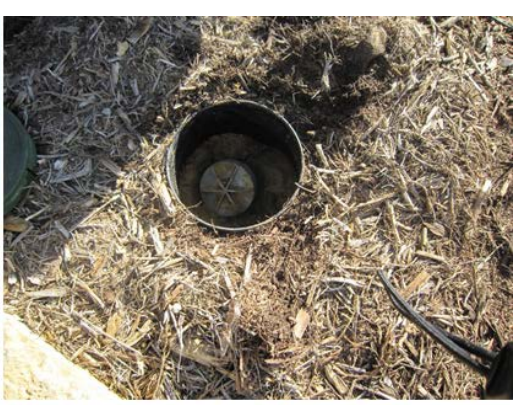

(b)

Figure 2. A local meteorological station (a) and soil moisture sensor (b) associated with the third-pipe irrigation system in "The Green".

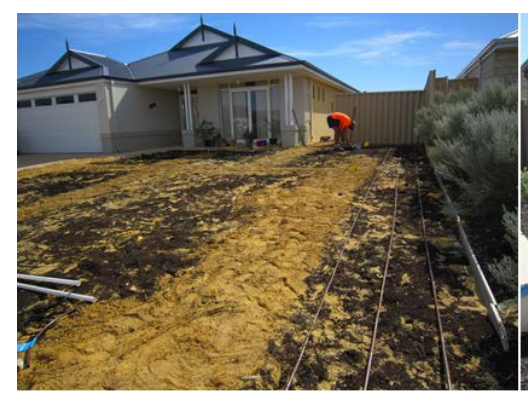

(a)

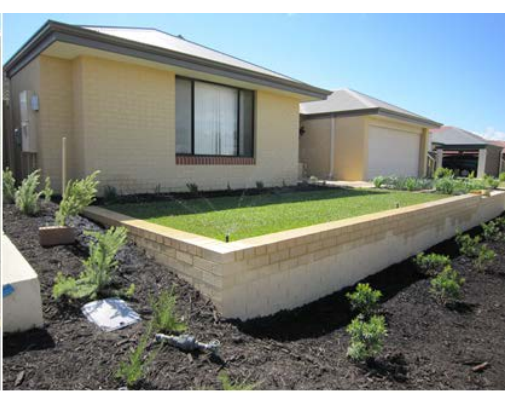

(b)

Figure 3. Photographs of garden bed preparation (a) and mulching (b) in "The Green". 
improve irrigation efficiency.

\subsection{Water Efficient Agriculture, Forestry, and Recreational Landscaping at Community}

In "The Green", community gardens, public parks, and recreational landscaping were designed in water efficient way. Usual sprinklers were replaced with subsurface drip irrigation practices (Figure 3(a) and Figure 5(c)) and the lawn areas were dropped and replaced with less water demanding natives and bushes (Figure 5(a)). Trees and bushland (Figure 5(b)) were retained in the parks, so that these parks could be utilized for multiple purposes, such as: playground and recreational activities, community gardening, improving bio-diversity, urban cooling, and community appearance.

Furthermore, a higher density development was adopted in "The Green" that reduced residential garden areas and eventually the residential irrigation demand. The reduced residential gardens were, however, compensated with increased community gardens, public open spaces and reserves [28] [30]. In addition, wide range of water sensitive land management practices were adopted, namely: porous pavement, bio-retention trenches and basins, grassed swales, terraced gardens, and artificial water bodies [22]. These practices would help reducing irrigation demand, improving irrigation efficiency, facilitating aquifer recharge, and recycling urban water and nutrients within the build environment. These innovative designs facilitated integrated and sustainable water management at local and urban level. The innovative irrigation and water sensitive land management practices were expected to be an important avenue for ensuring efficient and integrated land and water management [14], and improving neighbourhood appearance and liveability [31] at various spatial level.

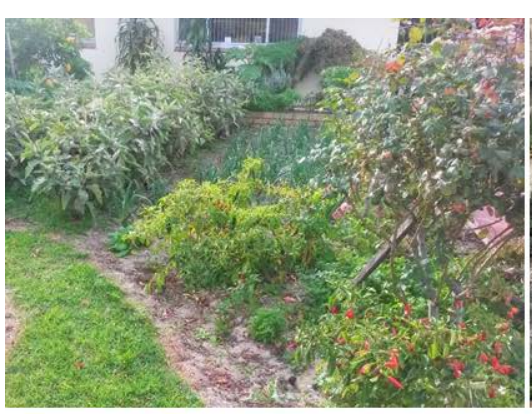

(a)

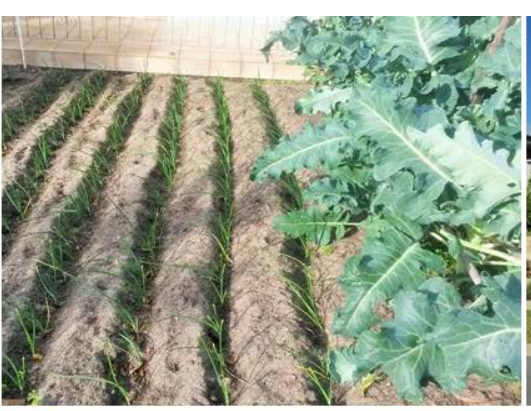

(b)

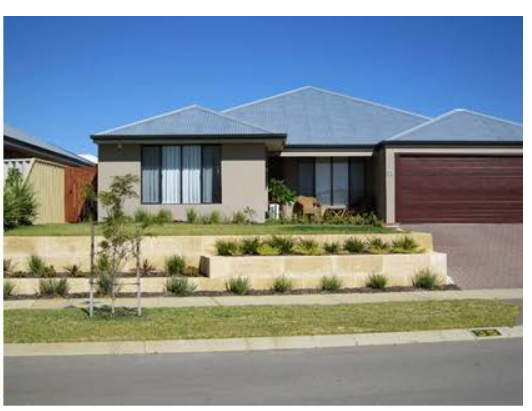

(c)

Figure 4. Photographs of veggie patches (a) and (b), and home garden (c) in "The Green".

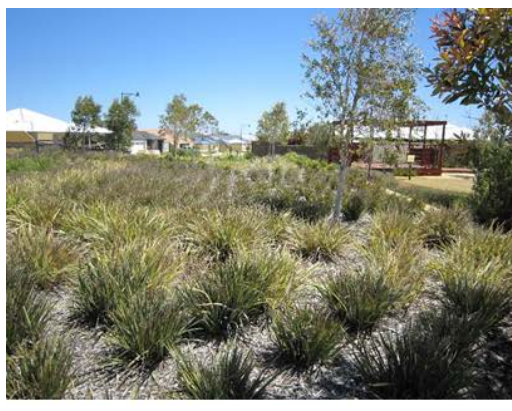

(a)

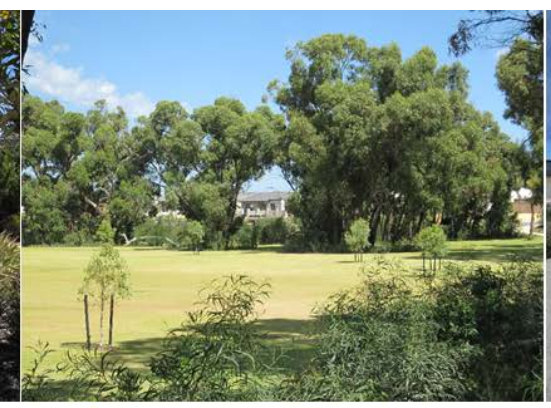

(b)

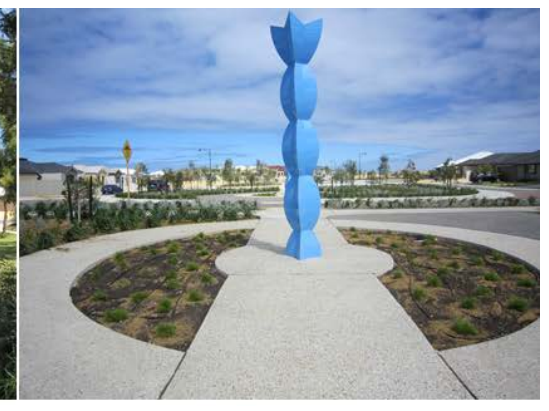

(c)

Figure 5. Public parks with (a) native plants, (b) trees and bushland, and (c) recreational landscaping in "The Green".

\section{Research Method}

A case study with mixed methodology was adopted to evaluate the agricultural irrigation efficiency and water conservation as a result of the fit-for-purpose irrigation system and water efficient urban development. This paper utilizes the secondary data on drinking water consumption, irrigation usage in gardens and parks and land use pattern to analyze the scheme water saving and irrigation efficiency at "The Green". The drinking water consumption and irrigation usage data were obtained from the Western Australian Water Corporation and land 
use data were obtained from the City of Wanneroo. At the same time, the qualitative information from survey and stakeholders interviews were analyzed to understand community acceptance and socio-economic challenges associated with the alternative irrigation system. The data were sorted, managed and analyzed using computer software: Microsoft Excel 2007, IBM SPSS 22, IBM SPSS Amos 22 and NVivo 9.

The drinking water supply was metered and measured in KL/year/household, whereas the groundwater irrigation supply was not metered. Hence a bulk amount of residential groundwater consumption was divided by the number of households connected to the irrigation system to get the average groundwater usage (in KL) per household per year. Similarly, the annual public open space irrigation usage was measured with the meter installed in each public parks and verges and given in ML/year.

The total household water usage was calculated as a sum of average drinking water consumption and irrigation usage. The comparative analysis of drinking water consumption data across the studied areas explained the drinking water conservation, whereas the analysis of total domestic water (Drinking and groundwater) usage data provided the net water efficiency situation at "The Green". The analysis of drinking water conservation was not restricted only for the survey participants. It utilized the data for the whole studied suburban areas to explore a complete picture of water conservation and irrigation efficiency scenarios.

\section{Results and Discussions}

\subsection{Water Conservation Scenario}

In "The Green", both drinking water and groundwater irrigation were supplied; whereas in Ridgewood and Perth metro region, only drinking water was supplied. "The Green" was started since 2007 but the number of households connected to the groundwater irrigation system was very low until 2010, hence only the data from 2011 were used for the analysis. In Table 1, the total household water consumption in "The Green" (drinking water and groundwater irrigation) is compared with that of Ridgewood and Perth metropolitan (only drinking water).

The average drinking water consumption in "The Green" was significantly lower compared to Ridgewood and Perth metropolitan for all times. A typical household in "The Green" consumed only half of the drinking water used by an average Perth Metropolitan household. Such a significant water savings in "The Green" was mainly because of groundwater irrigation system that replaced the drinking water usage in garden irrigation and other outdoor agricultural activities.

As shown in Table 1, the total household water consumption in "The Green" in 2012 appeared to be significantly higher than neighbouring suburban areas and metropolitan average. It could be attributed to increased usage of groundwater $(188 \mathrm{KL})$ for new garden establishment, and other once-off usage such as construction works. It became further evident from continuous reduction in total water consumption in next two consecutive years (Table 1).

It should be noted that a newly established garden or lawn in Perth metropolitan could get irrigation exemption for up to 42 days in summer and 35 days in winter. During exemption period, a significant amount of water $(10 \mathrm{~mm} /$ day in summer, and $7.5 \mathrm{~mm} /$ day in winter) would be consumed [34]. This was supposed to be the main reason for the higher amount of groundwater consumption in "The Green" given the number of newly established garden and lawns. This figure could get higher, but the water efficient irrigation system and land management practices help to restrain it.

As shown in Figure 6, the household irrigation consumption in "The Green" appeared to be significantly higher than allocated, whereas the public parks irrigation consumption figures were far below than the allocation limit. This could be linked again to the large number of irrigation exemptions for newly established gardens across "The Green" suburb in 2013, which was supported with the reduced consumption in successive years (Table 1). Whereas the groundwater consumption for public open space irrigation in "The Green" was significantly lower than the allocation limit as well as the average public open space irrigation in surrounding suburban areas and metropolitan figures. This indicates that the water efficient irrigation technology and the water sensitive land management practices could significantly reduce the irrigation demand of public parks, verges, and other green infrastructures at the urban setting. The findings supports the empirical ideas on irrigation efficiency and urban water conservation put forth by Wong [19], Water Corporation [15], and Barron, Wendling, Tucker, Green, Devkota and Donn [18].

It is equally important to note that the irrigation in "The Green" is sourced from superficial aquifer, which is 
Table 1. Water consumption (KL/household) in "The Green", Ridgewood, Butler, and Perth metropolitan region [32] [33].

\begin{tabular}{|c|c|c|c|c|c|c|c|c|c|c|}
\hline Areas $\backslash$ Years & 2005 & 2006 & 2007 & 2008 & 2009 & 2010 & 2011 & 2012 & 2013 & 2014 \\
\hline Perth Metro* & 375.0 & 387.5 & 362.5 & 362.5 & 352.5 & 347.5 & 344.3 & 331.5 & 336.6 & 347.5 \\
\hline Ridgewood & 265.9 & 178.7 & 165.0 & 253.8 & 300.7 & 302.6 & 285.2 & 285.5 & 292.6 & 282.9 \\
\hline $\begin{array}{l}\text { Butler (except } \\
\text { "The Green") }\end{array}$ & 258.7 & 282.6 & 371.1 & 391.0 & 364.2 & 346.2 & 333.6 & 290.9 & 269.5 & 278.3 \\
\hline The Green-Drinking Water & & & & 6.7 & 37.9 & 91.3 & 116.9 & 154.4 & 167.6 & 172.3 \\
\hline -Groundwater & & & & & & & 54.1 & 188.8 & 167.5 & $115^{\Psi}$ \\
\hline -Total & & & & 6.7 & 37.9 & 91.3 & 171.0 & 343.3 & 335.1 & $287.3^{\Psi}$ \\
\hline
\end{tabular}

${ }^{*}$ Household water consumption for Perth Metropolitan is calculated as a multiplication of average household size (2.6) with the average per-capita water consumption for each year. "The allocated groundwater for residential irrigation in "The Green" is approximately 115 KL/household for $2013 / 14$

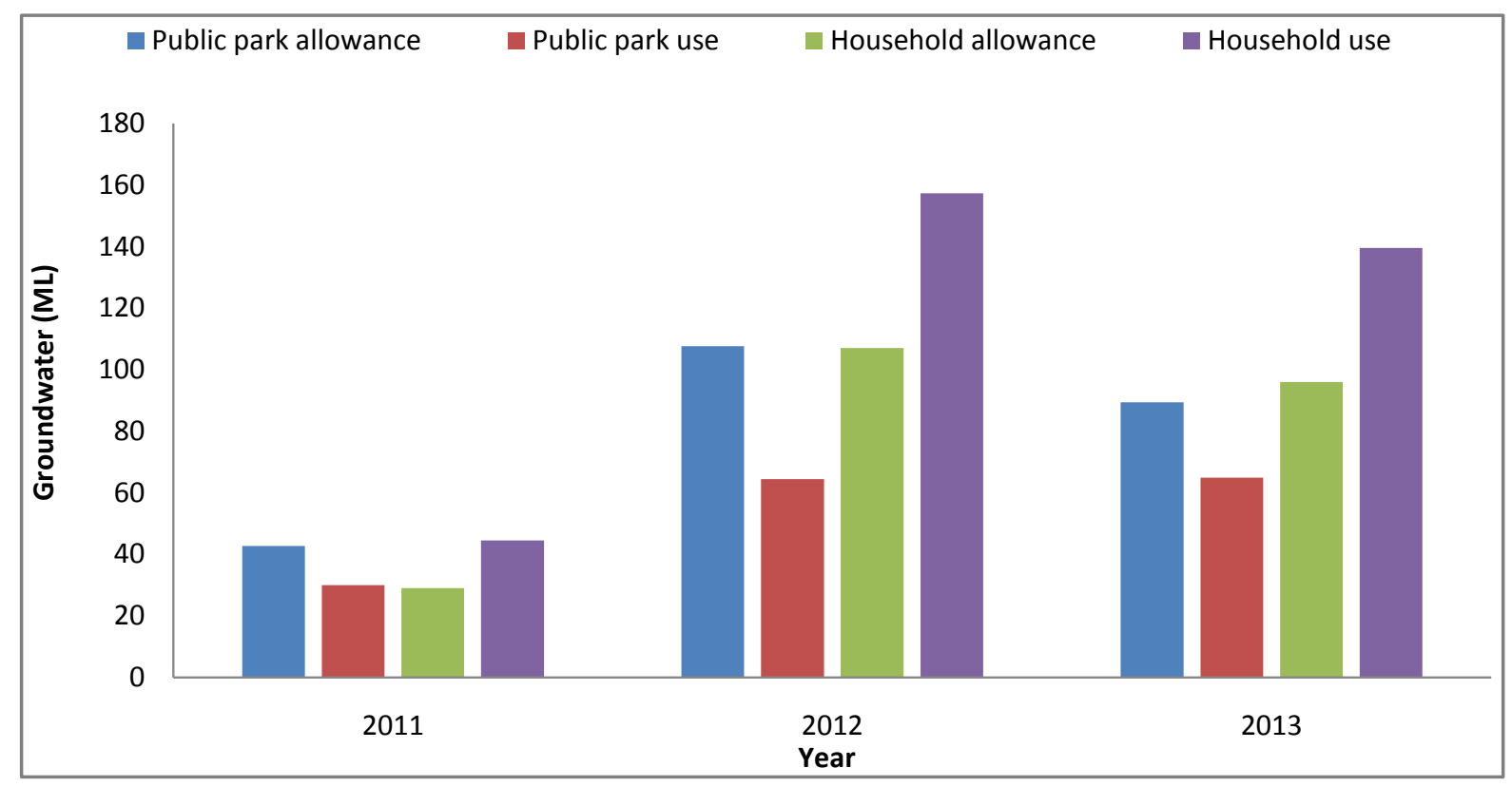

Figure 6. Total groundwater allocation and consumption in "The Green".

directly recharged by rainfall. The water sensitive land management practices implemented in "The Green" were reported to increase the aquifer recharge by $383 \mathrm{ML}$ per year than that of pre-development conditions. It was also noticed that after abstracting $209 \mathrm{ML} /$ year for groundwater irrigation network, still there would be an increase in net aquifer recharge by $174 \mathrm{ML} /$ year [35]. Such an increase in aquifer recharge indicates that the groundwater would be a sustainable source for irrigating urban agriculture, vegetation, and recreational landscaping as shown by previous studies of Western Australian Planning Commission [14], and Nolasco [4].

The irrigation trial has been operated for seven years but still approximately $20 \%$ of blocks are to be developed. Though new blocks are yet to be connected, the trend in water saving and irrigation efficiency is quite promising. Almost 50\% less drinking water demand at residential settings and significant reduction in irrigation for agricultural activities in "The Green" than surrounding suburban areas and metropolitan average clearly indicate that the trialled system will achieve its target even at the full residential development of the suburb. 
However, an overconsumption of groundwater that was evident in "The Green" could be linked mainly to irrigation exemptions and other once-off usage. These transitional irrigation inconsistencies, as observed in Mawson Lakes Australia [17], would gradually settle down after the suburban areas completely developed and irrigation system fully connected. Having said that, the complete analysis for the factors and parameters associated with the success of the irrigation trial requires completion of the residential development and longitudinal data on usage and behaviour towards water and irrigation systems. Joint effort of Urban Agriculturist, water providers and urban planners.

\subsection{Inherent Socio-Economic Challenges}

The community perceptions were found to be positive towards the efficient irrigation system and a majority of the consumers were reported to be satisfied with the system in "The Green". The higher level of satisfaction was mainly associated with the automatic irrigation operation, water savings, environmental benefits, and the trust on irrigation service providers. However, there were some social and economic challenges, mainly lack of clarity in institutional roles, and management of consumer expectations that need to be addressed for better management of potential alternative irrigation systems. This study shows that the fit-for-purpose irrigation with integrated land and water management brings the community members, government authorities, and service providers together to plan, implement and develop sustainable urban agricultural practices, and share mutual benefits.

\subsection{Challenges in System Replication}

The qualitative data analysis clearly shows that the majority of residents participated positively towards the efficient irrigation system for food production and agricultural activities at their home and community. Further, it shows an increasing awareness towards the efficient gardens and irrigation system in "The green" community. This is an important finding for the future development of urban agricultural activities with reliable efficient irrigation systems in similar location and climate across Australia.

Based on the findings of this study, alternative irrigation system sourced from rainwater has been successfully implemented in a neighbouring suburban area (Evermore Height, Alkimos). Successive new alternative irrigation projects in the Perth metropolitan and regional areas have also being formulated and developed taking Butler trial as a successful urban agriculture irrigation model [30]. These findings and successful replications clearly demonstrate that the fit-for-purpose irrigation system is instrumental in sustainable development of urban agriculture across Australia.

\section{Conclusion}

An alternative fit-for-purpose irrigation system was trialled in "The Green" community at Butler, Perth to understand sustainable water management for urban agriculture. The quantitative and qualitative data were collected and analyzed. The study suggested that a fit-for-purpose irrigation was a sustainable alternative for urban agriculture. Additionally, it offers significant irrigation efficiency in urban agriculture, and consequent reduction in water demand at urban residential settings. The water quality issues associated with fit-for-purpose irrigation appear to be nominal and do not affect the community acceptance. This indicates that the fit-for-purpose irrigation system with water efficient land management practices is highly encouraging for the sustainable development of urban agriculture and recreational landscaping across spatial levels.

\section{Acknowledgements}

Authors greatly acknowledge the key contribution of WA Water Corporation who provided relevant data and the fund to undertake this study. We thank Satterley Property Group for their financial contribution; Centre for Planning at Edith Cowan University for the operational management of the study. We are also grateful for Mr. Tim Perkins (Centre for Planning, ECU) and Dr. Bishnu Devkota (Infra Tech Pacific/WorleyParson, past-WA Water Corporation) for their generous comments on this paper.

\section{References}

[1] Mougeot, L.J.A. (2010) Agropolis: The Social, Political and Environmental Dimensions of Urban Agriculture. IDRC, 
London.

[2] Zezza, A. and Tasciotti, L. (2010) Urban Agriculture, Poverty, and Food Security: Empirical Evidence from a Sample of Developing Countries. Food Policy, 35, 265-273. http://dx.doi.org/10.1016/j.foodpol.2010.04.007

[3] Urban Agriculture Australia (2013) What Is Urban Agriculture and Why It Is Important? Urban Agriculture Australia, Canberra.

[4] Nolasco, J. (2013) Sustainable Water Management for Urban Agriculture: Planting Justice. Pacific Institute, Oakland.

[5] Lin, B.B., Philpott, S.M. and Jha, S. (2015) The Future of Urban Agriculture and Biodiversity-Ecosystem Services: Challenges and Next Steps. Basic and Applied Ecology, 16, 189-201. http://dx.doi.org/10.1016/j.baae.2015.01.005

[6] Lin, B.B. and Fuller, R.A. (2013) FORUM: Sharing or Sparing? How Should We Grow the World's Cities? Journal of Applied Ecology, 50, 1161-1168.

[7] Lwasa, S., Mugagga, F., Wahab, B., Simon, D., Connors, J.P. and Griffith, C. (2015) A Meta-Analysis of Urban and Peri-Urban Agriculture and Forestry in Mediating Climate Change. Current Opinion in Environmental Sustainability, 13, 68-73. http://dx.doi.org/10.1016/j.cosust.2015.02.003

[8] Lovell, S.T. (2010) Multifunctional Urban Agriculture for Sustainable Land Use Planning in the United States. Sustainability, 2, 2499-2522. http://dx.doi.org/10.3390/su2082499

[9] Guendel, S. and Richards, W. (2002) Peri-Urban and Urban Livestock Keeping in East Africa-A Coping Strategy for the Poor, Scoping Study Commissioned by DFID. Natural Resources Institute, Aylesford.

[10] Nugent, R. (2000) The Impact of Urban Agriculture on the Household and Local Economies. In: Bakker, N., Dubbeling, M., Gündel, S., Sabel-Koshella, U. and de Zeeuw, H., Eds., Growing Cities, Growing Food. Urban Agriculture on the Policy Agenda, Zentralstelle für Ernährung und Landwirtschaft (ZEL), Feldafing, 67-95.

[11] Mok, H.-F., Williamson, V., Grove, J., Burry, K., Barker, S.F. and Hamilton, A.J. (2014) Strawberry Fields Forever? Urban Agriculture in Developed Countries: A Review. Agronomy for Sustainable Development, 34, 21-43. http://dx.doi.org/10.1007/s13593-013-0156-7

[12] Cohen, N. and Reynolds, K. (2015) Resource Needs for a Socially Just and Sustainable Urban Agriculture System: Lessons from New York City. Renewable Agriculture and Food Systems, 30, 103-114. http://dx.doi.org/10.1017/S1742170514000210

[13] Water Corporation (2010) Perth Residential Water Use Study 2008/2009. Water Corporation, Perth.

[14] Western Australian Planning Commission (2008) Better Urban Water Management. Western Australian Planning Commission, Perth.

[15] Water Corporation (2009) Water Forever: Towards Climate Resilience. Water Corporation, Perth.

[16] Smith, A., Pollock, D. and McFarlane, D. (2005) Opportunity for Additional Self Supply of Groundwater from the Superficial Aquifer beneath Metropolitan Perth. CSIRO: Water for a Healthy Country National Research Flagship, Canberra.

[17] Hurlimann, A. (2008) Community Attitudes to Recycled Water Use: An Urban Australian Case Study Part 2. CRC for Water Quality and Treatment, Salisbury.

[18] Barron, O., Wendling, L., Tucker, D., Green, M., Devkota, B. and Donn, M. (2010) Investigation of Techniques to Better Manage Western Australia's Non-Potable Water Resources. CSIRO: Water for a Healthy Country National Research Flagship, Canberra.

[19] Wong, T.H. (2007) Water Sensitive Urban Design—The Journey Thus Far. Australian Journal of Water Resources, 10, 213-222.

[20] Po, M., Nancarrow, B.E., Leviston, Z., Porter, N.B., Syme, G.J. and Kaercher, J.D. (2005) Predicting Community Behaviour in Relation to Wastewater Reuse: What Drives Decisions to Accept or Reject? CSIRO: Water for a Healthy Country National Research Flagship, Perth.

[21] Nancarrow, B.E., Leviston, Z., Po, M., Porter, N.B. and Tucker, D.I. (2008) What Drives Communities' Decisions and Behaviours in the Reuse of Wastewater. Water Science and Technology, 57, 485-491. http://dx.doi.org/10.2166/wst.2008.160

[22] Davis, C. and Farrelly, M. (2009) Demonstration Projects: Case Studies form Perth, Australia. National Urban Water Governance Program, Monash University, Melbourne.

[23] Davis, C. and Farrelly, M. (2009) Demonstration Projects: Case Studies form Melbourne, Australia. National Urban Water Governance Program, Monash University, Melbourne.

[24] Davis, C. and Farrelly, M. (2009) Demonstration Projects: Case Studies form South East Queensland, Australia. National Urban Water Governance Program, Monash University, Melbourne.

[25] Department of Water (2010) Predicting the Future Demand for Water Resources in Western Australia. Department of 
Water, Perth.

[26] Dzidic, P. and Green, M. (2012) Outdoing the Joneses: Understanding Community Acceptance of an Alternative Water Supply Scheme and Sustainable Urban Design. Landscape and Urban Planning, 105, 266-273. http://dx.doi.org/10.1016/j.landurbplan.2011.12.023

[27] Water Corporation (2005) Integrated Water Supply Scheme Source Development Plan 2005: Planning Horizon 2005-2050. Water Corporation, Perth.

[28] Water Corporation (2007) Memorandum of Understanding: "The Green" at Brighton (Brighton Village 4) Superficial Groundwater Demonstration Project. Water Corporation, Perth.

[29] Water Corporation (2007) Brighton Superficial Groundwater Supply Demonstration Project: Health Risk Management Plan. Water Corporation, Perth.

[30] Satterley Property Group (2010) The End to the Waste of Precious Water Starts Here: Smartwater Initiative, The Green. Satterley Property Group, Perth.

[31] Western Australian Planning Commission (2007) Liveable Neighbourhood: A Western Australian Government Sustainable Cities Initiatives. Western Australian Planning Commission, Perth.

[32] Australian Bureau of Statistics (2013) 2011 Census Population and Housing: Greater Perth—Basic Community Profile (Catalogue Number 2001.0). Australian Bureau of Statistics, Canberra.

[33] Water Corporation (2015) Reducing Water Use. Water Corporation, Perth.

[34] Water Corporation (2015) Exemptions. Water Corporation, Perth.

[35] GHD (2006) Satterley Property Group: Report on Brighton Stage 4. Hydrological Assessment. GHD, Perth. 